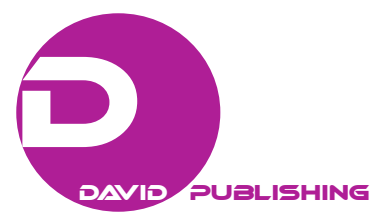

\title{
A Comparative Analysis of the Role of International Organizations in Financing Higher Education System: A Case Study of Nigeria and Cambodia*
}

\author{
DY Channy, Ogunniran, Moses Oladele \\ Beijing Normal University, Beijing, China
}

\begin{abstract}
Among the key international organizations (IOs) operating in Nigeria and Cambodia in terms of activities impact are the World Bank, the International Monetary Fund (IMF), European Union (EU), the United Nations Children's Fund (UNICEF), the United Nations Educational, Scientific, and Cultural Organization (UNESCO), and many Non-Governmental Organizations (NGOs) operating from both within and outside the two nations. Generally, the article accessed the impact of these IOs in higher education (HE) system of Nigerian and Cambodia. The major key goals of IO in both nations is to develop education policy, enhance quality of HE, prepare equity of accessing for HE, provide ideas of conducting researches, and provide plenty scholarship opportunities, but for several years, this goals are yet to be accomplished in both nations. In Nigeria context, the major reason for the frequent academic and non-academic strike as result of inadequate funding. While in Cambodia context, the major course of HE slow growth, poor infrastructure, and inadequate manpower, unemployment is as a result of weak intervention of IO in HE. Using secondary data, the paper reviews literatures in accessing the role of IO in financing HE system of both countries. The paper ended with recommendations that all IO should collaborate with the World Bank to impact HE in both countries. We also suggested that more attention should be withdrawn from basic education to HE into other to enhance rapid development of human capital.
\end{abstract}

Keywords: international organisation (IO), higher education (HE) system in Nigeria and Cambodia, Higher Education Finance in Nigeria and Cambodia

\section{Introduction}

International organizations (IOs) are organizations with an international membership, scope, or presence. They tend to operate in many countries of the world. IOs are of two types: non-governmental and governmental IOs. Among the key IOs in education operating in Nigeria and Cambodia are the World Bank, the International Monetary Fund (IMF), European Union (EU), the United Nations Children's Fund (UNICEF), The United

\footnotetext{
*Acknowledgment: I acknowledge the effort of Prof. David Turner for his mentoring, supervision, constant help, and forthright attitude at every point which has helped me a lot to work in time. Secondary, to my highly respectable colleague, Moses who is the corresponding author of this paper. Thank you for your remarkable guide, contribution, and advice towards the success of this paper. Thank you Prof. David and Moses.

DY Channy, Ph.D., Faculty of Education, Institute of International and Comparative Education (Educational Leadership and Policy), Beijing Normal University.

Ogunniran, Moses Oladele (Corresponding author), Ph.D., Faculty of Education, Institute of International and Comparative Education (Educational Leadership and Policy), Beijing Normal University.
} 
Nations Educational, Scientific, and Cultural Organization (UNESCO), and many others coupled with myriad of Non-Governmental Organizations (NGOs) operating from both within and outside the country.

Created alongside with the IMF, the World Bank was established in 1944 after the Second World War and was primarily intended to help rebuild structures, facilities, and infrastructures that were severely damaged during the Second World War. It was also intended to help improve status and faces of infrastructures and capital projects in developing economies through the provision of medium to long term loans at zero and/or low interest rate.

The World Bank later transformed into International Financial Institution that provides loans to all countries of the world for capital projects. The World Bank comprises two institutions, which are the International Bank for Reconstruction and Development (IBRD) with 189 member countries and International Development Association (IDA) with 173 member countries. The World Bank is a component of the World Bank Group. The major goal of the World Bank is to "Three priorities guide our work with countries to end poverty and boost prosperity for the poorest people. Helping to create sustainable economic growth, the surest path out of poverty. Investing in people through access to health care, education, water, sanitation, and energy. Building resilience to shocks and threats that can roll back decades of progress” (World Bank, 2018).

The UNICEF which was established on December 11, 1946 is aimed at children's welfare. Among the child survival activities that UNICEF focuses on are: early childhood development, HIV/AIDS, nutrition, health, immunization, and wash. Education is a fundamental human right. UNICEF holds that every girl and boy, everywhere, is entitled to attend school and learn. UNICEF is dedicated to ensuring that all children can enjoy access of right to a quality education, essentially from early learning opportunities that provide foundations for excellence.

On global basis, more children of primary school age are likely to miss out education than others. Though such deprivation seems to have relatively permanent consequences that often extend to the next generation. Inequality and deprivation that arise there from disrupt the potentials of both individuals and societies.

To help address the barriers that stand in the way of getting all children in school and learning, UNICEF's work focuses particularly on the children who are excluded. Noting that just getting children enrolled is not enough, UNICEF works to promote child-friendly approaches that guarantee safely secured and healthy learning environments, and teaching and learning processes that address children's individual needs—so that children can acquire the skills and knowledge they need.

UNESCO which was established on November 4, 1946 was intended to lift and support nations in educational, scientific, and cultural spheres. UNESCO's aim is "to contribute to the building of peace, the eradication of poverty, sustainable development, and intercultural dialogue through education, the sciences, culture, communication, and information”. It offers nations of the world policy access and prescriptions to that effect.

The IMF was established at Bretton Woods Conference in 1944 is aimed at helping nations on their balance of payments positions. The IMF operates as a global hub for knowledge sharing on issues that are financial and economic. Over many decades, it has developed world-leading expertise and a repository of experience on what policies work, why they lead to growth, and how best to implement the policies. In summarily, the IMF's knowledge sharing work concentrates on public finances, monetary and financial systems, legislative frameworks, statistics, and macro-economic frameworks. IMF concerns itself with advising policies that help economies stabilize and foster economic growth. 
The World Bank impacts on education having acknowledged education as one of the avenues for investing in people. This role has, over the years, affected all levels of education. For example, the World Bank has worked to increase enrollment at primary, secondary, and post-secondary levels. Evidently, data from World Development Indicators is a proof to the positive trend in enrollments.

The World Bank Group continues to be a long-standing member of Global Partnership for Education (GPE) which was established in 2012 as an Education for All Fast Track Initiative. GPE was targeted at Millennium Development Goals 2 and 3 (achieve universal primary education, promote gender equality and empower women) as well as the education for all goals. These MDG' goals were agreed in Dakar in 2000.

As education system allows different levels for students to pass through, each level is constructed to serve separated special purposes. Spending more than 15 years, learners will reach the higher education (HE) level which is the bigger gate before entering to the society and employment. According to Bloom (1956), the long journey in learning will enhance the learners rigorously to obtain three domains including cognitive domain, psychomotor domain, and affective domain. In other words, HE will develop human resource with excellent knowledge, skills, and moral values under the purpose of living and working together peacefully in the era to globalization and knowledge-based society. Moreover, "HE is central to the development of active citizenship, knowledge, source for present and future wealth, and prosperity" (Ministry of Education, Youth, and Sport [MoEYS], 2014). It undoubtedly enhances intellectual capacity and produces essentially creative leadership in all fields of country's activities preparing and supplying skill-educated graduates with the labor market demands.

\section{An Overview of HE in Nigeria and Cambodia}

\section{HE in Nigeria}

HE essentially refers to any education following that of secondary education and which includes education acquired in universities, polytechnics, and colleges of education. The government of the country has always encouraged the pursuit of $\mathrm{HE}$ and this is reflected in the continual establishments of higher institutions of learning, both by governments and private individuals, as a consequence of both government laws and liberalization policy.

In order to enable smooth organization, high standards and regulated orderliness in the establishment and running of higher institutions of learning, various regulatory authorities have been set up. In 1962, National Universities Commission (NUC) was established to see to the affairs of the universities in the country. Analogously, National Board for Technical Education and National Commission for Colleges of Education were subsequently established to oversee the affairs of the polytechnics and colleges of education respectively.

The demand for education can be explained in terms of derived demand, both in micro-economic and macro-economic context. At individual level, each individual demands education, especially at tertiary level, in order to earn such benefits, such as being informed and getting a higher certificate with potentially accompanying chances of securing highly paid jobs. At national level, the demand for education is increasingly higher than as perceived at individual level and it derives essentially from the need to invest in and develop human capital with a view to growing, and consequently, developing the nation's economy. A global perspective of education includes the advocacy by IOs, such as the United Nation enshrined in the Millennium Development Goals (MDGs). The aim of educational demand by IOs is aimed at raising global literacy and output on premises of findings by several studies which posit that education and output are positively related. 
In the context of Nigerian educational system, HE refers to the level of education, following those of primary and secondary levels and which essentially comprise universities, polytechnics, and colleges of education. The ownership and management structures of these higher institutions of learning vary from government levels to private individuals, following the liberalization of education sector which simultaneously allows and accounts for increased private participation in the provision of HE in the country.

Historically, HE in Nigeria began with the establishment of Yaba College of Technology in 1932 as the first tertiary institute in Nigeria by the British Colony. Following its establishment, Nigerian nationalists protested and rejected it, saying that what the nation needed then was a university and not a polytechnic. This led to the establishment of the University College, Ibadan (Now University of Ibadan), in 1948. The university was founded on its own site on November 17, 1948. The university was originally instituted as an independent external college of the University of London, when it was called University of College, Ibadan. The University of Ibadan became an independent university in 1962. Consequently, a good number of universities have added, ranging from government-owned universities to private ones. At present, there are about 108 universities in the country, comprising 41 federal universities, 47 state universities, and 20 private universities.

The word "polytechnic" is used generically to cover the polytechnics and mono-technics/specialized institutions in the country and it is next to the university education both in terms of level (attached grade level) and applicants' preference. The first polytechnic in the country was earlier identified as the Yaba College of Technology, Lagos. Since then, there has been a growing number in the number of polytechnics in the country. The polytechnics offer a variety of technical, technological/business programmes to the level of National Diploma (ND), Higher National Diploma (HND), and Post-HND. There are at present about 90 polytechnics in the country.

Next to this are colleges of education which are established to train teachers for lower educational levels which are formally primary and secondary schools. The history of teachers' education in Nigeria commenced around 1860 in Ogun State Capital, Abeokuta. The first institution in control of teachers' training was called "The Training Institution” organized by the Church Missionary Society.

The school was later moved to Oyo to become the St Andrew College and later upgraded to be the Oyo State College of Education. Other colleges of education have, since then, come up, so that the country currently has 109 colleges of education distributed as 21 federal, 46 state, and 42 private colleges of education.

As earlier noted, the liberalization of the establishment of universities to increase access has led to many universities coming up on stream in the past few years. Besides, most students seem to prefer universities to polytechnics and colleges of education. Increasing demand for university education becomes necessary following rising discrimination against those in polytechnics and colleges of education, and more unfortunately on grounds that the source of such discrimination does not exclude the government. Limited source of supply of university education in the country necessitates the import of education as some Nigerians choose to pursue same education abroad from year to year.

\section{HE in Cambodia}

Democratic Kampuchea (1975-1979) was the perfect name to identify the freedom society. In contrast to that, it was replaced by new name called "Pol Pot regime", "the Black Period", or "the Killing Field", which most of local and international diversified background authors and writers have briefly introduced to state about the "ground-zero" nation especially the demolition of entire education system (Chhinh, 2004; Dy, 2014; Keng 
\& Clayton, 2007; K. Dy, 2007; Hattori, 2009; Chet, 2009; Chhinh \& Dy, 2009; Kim \& Ruose, 2011; CDRI, 2012; K. Dy, 2013; S. Dy, 2013; Sen \& Ros, 2013; MoEYS, 2014; MoEYS \& World Bank, 2015; Shaeffer \& Heng, 2016; Chhinh, 2016; Chhihn, Ewards, James, Williams, \& Kitamura, 2016; Williams, Kitamura, \& Keng, 2016). They ordinarily referred to the introductory suffering memory rather clearly identified that this black period still affects the slow growth of current education system. However, "the legacy of the virtual destruction of the entire system remains to this day because of a large part of the intelligentsia was lost” (Williams et al., 2016, p. 168). There were 1.5 million people were killed and died including teachers, doctors, or other scholars who wore glasses and spoke foreign languages (K. Dy, 2013). It was estimated that those people were $75 \%$ of teachers, $96 \%$ of university students, and $67 \%$ of all primary and secondary school pupils (Cheat, 2005; Benveniste, Marshall, \& Araujo, 2008; UNESECO, 2008). Before Khmer Rouge era, in 1960, the first university was built - the Khmer Royal University. Five years later, in 1995, the other six higher institutions were also established. However, according to Pith and Ford (2004), those seven universities provided extremely low quality of education. Nowadays, Cambodian HE was re-established 21 years ago, there are a lot of young famous universities which lately built around the world, so the time is long enough not to affect by that regime. Today’s low quality should discuss today’s problems.

Table 1

Of HEIs Under Relevant Ministries/Institutions

\begin{tabular}{llll}
\hline Ministries/Institutions & State & Private & 73 \\
\hline MoEYS & 13 & 60 & 25 \\
Ministry of Labor and Vocational Training & 12 & 13 & 5 \\
Ministry of National Defense & 5 & 0 & 3 \\
Ministry of Culture and Religion & 3 & 0 & 3 \\
Ministry of Agriculture, Forestry, and Fishery & 3 & 0 & 2 \\
Ministry of Health & 2 & 0 & 1 \\
Ministry of Culture and Fine Arts & 1 & 0 & 1 \\
Ministry of Interior & 1 & 0 & 1 \\
Ministry of Public Work and Transport & 1 & 0 & 1 \\
Ministry of Social Affairs, Veterans, and Youth Rehabilitation & 1 & 0 & 1 \\
Ministry of Mine and Energy & 1 & 0 & 1 \\
Ministry of Post and Telecommunication & 1 & 0 & 1 \\
Ministry of Economic and Finance & 1 & 0 & 1 \\
Ministry of Land Management, Urban Planning, and Construction & 1 & 0 & 1 \\
Office of the Council Minister & 1 & 0 & 121 \\
National Bank of Cambodia & 1 & 0 & 73 \\
Total & 48 & & 1 \\
\hline
\end{tabular}

Source: Education congress: The education, youth, and sport performance in the academic year 2015-2016 and goals for the academic year 2016-2017.

Long time after Democratic Kampuchea, in 1997, the Royal University of Phnom Penh was reopened with other universities that were established before this era. At the same, the first private university was also given license to run in Cambodia because of the policy changes which all those national universities officially became administrative institutions and developed into semi-autonomous (Cheat, 2005; Williams et al., 2016). At present, there are 121 higher education institutions (HEIs), which are 48 state HEIs and 73 private HEIs, across the country in total located in $20 \mathrm{capital} /$ provinces. All HEIs are under supervision of 16 government 
ministries/institutions. Practically, MoEYS controls 73 (13 states and 60 private), out of 121 HEIs with only 38 HEIs provided post-graduate courses (MoEYS, 2017).

HE is mainly divided into two interrelated streams focusing on academic and vocational under supervision of MoEYS, Ministry of Labor and Vocational Training, and other specialized government ministries that involved in providing HE services as shown in the above Table 1. In addition, HEIs are basically categorized into three different paradigms shift, the royal academic, university, and institution, or independent specialized school. Unfortunately, human resource problem in providing think tank function for research activities and consultancy in royal academic and some independent specialized schools and faculties upgraded themselves to universities make all the three categories almost become equally function as normal HEIs (Cheat, 2009).

\section{Regulatory Authorities of HE in Nigeria}

NUC, the body was established in 1962 as an administrative unit in the cabinet office and it became a statutory body in 1974 with a board to see to the implementation of its mandates which have since been expanded to include the following:

1. Monitoring of universities;

2. Approval of courses and programmes;

3. Determination and maintenance of minimum academic standards;

4. Accreditation of academic programmes;

5. Provision of guidelines and processing of applications for the establishments for the establishment of private universities.

\section{Literature Review}

\section{Financing HE in Cambodia}

Education sector is provided about 2\% of GDP. However, HE subsector's expense is unclear (Cheat, 2009).

IOs and Education Projects in Cambodia. MoEYS formulated 27 projects for three years rolling public investment program. There are 21 projects on going and 6 projects are newly requested. These projects will spend the total amount of USD 208.5 million.

About the aid financing, it is notice that 2016 amount increased USD 90 million comparing to 2015 provide by the top 10 development partners. The EU is the top 1.

At present, HE gradually improves with some great achievements. However, there are some challenges that need the effective ways to solve. Those problems include the number of scholarship students selected for HE is below the target; capacity to absorb students in provincial HEIs is limited; shortage of human, material, and financial resources for STEM training; shortage of fund for HE research; and lack of regulation on autonomy and management of HEIs (MoEYS, 2017). Cambodia needs to enhance its ability in term of industrial development, economic empowerment, and human resource capacity to compete with the new Asian Economic Community (AEC) involving the relevance of quality of HE. So, the Royal Government of Cambodia together with the Ministry of Education and the Development Partners especially the IOs corporately work to solve them. 
Table 2

Financing Plan for HE in Cambodia

\begin{tabular}{lrrrrr}
\hline & \multicolumn{5}{c}{ Costs in Riels million } \\
\hline Activities & 2006 & 2007 & 2008 & 2009 & 2010 \\
\hline 1. Institutional support and operation & 5,340 & 5,810 & 6,300 & 6,770 & 7,240 \\
2. Strengthening of monitoring system and quality in HE & 160 & 190 & 200 & 230 & 260 \\
Resources: Total & 5,500 & 6,000 & 6,500 & 7,000 & 7,500 \\
\hline
\end{tabular}

Source: Education Sector Support Program, moneys.

Table 3

Pubic Investment Program (PIP), 2013-2015 to 2017-2019 (in USD Thousand)

\begin{tabular}{|c|c|c|c|c|c|c|c|c|}
\hline \multirow{3}{*}{ Year } & \multicolumn{2}{|c|}{$\begin{array}{l}\text { Total No. of assistance } \\
\text { projects }\end{array}$} & \multicolumn{4}{|c|}{ On-going projects } & \multicolumn{2}{|c|}{ Projects being negotiation } \\
\hline & \multirow[t]{2}{*}{ Project } & \multirow[t]{2}{*}{ Amount } & \multicolumn{2}{|c|}{ Investment project } & \multicolumn{2}{|c|}{$\begin{array}{c}\text { Technical assistance } \\
\text { project }\end{array}$} & \multirow[t]{2}{*}{ Projects } & \multirow{2}{*}{$\begin{array}{l}\text { Planned } \\
\text { budget }\end{array}$} \\
\hline & & & Project & Amount & Project & Amount & & \\
\hline $2013-2015$ & 41 & 231,833 & 1 & 1,190 & 22 & 141,192 & 18 & 88,671 \\
\hline $2014-2016$ & 29 & 266,571 & 2 & 21,500 & 14 & 116,792 & 13 & 128,278 \\
\hline $2015-2017$ & 27 & 198,292 & 5 & 49,570 & 13 & 98,109 & 9 & 50,619 \\
\hline $2017-2018$ & 27 & 186,291 & 7 & 57,953 & 13 & 37,969 & 7 & 90,369 \\
\hline 2018-2019 & 27 & 208,481 & 14 & 157,055 & 7 & 5,540 & 6 & 45,885 \\
\hline
\end{tabular}

Source: Education congress: The education, youth, and sport performance in the academic year 2015-2016 and goals for the academic year 2016-2017.

Table 4

Aid Financing of Top 10 Development Partners in Education Sector (in USD Thousand)

\begin{tabular}{|c|c|c|c|c|c|c|}
\hline Donors & $\begin{array}{l}\text { Expenditure } \\
2014\end{array}$ & $\begin{array}{l}\text { Expenditure } \\
2015\end{array}$ & $\begin{array}{l}\text { Expenditure } \\
2016 \\
\end{array}$ & Planned 2017 & Planned 2018 & Planned 2019 \\
\hline EU & 1,021 & 8,498 & 24,149 & 28,615 & 361 & N/A \\
\hline World Food Program & 9,958 & 8,910 & 14,910 & N/A & N/A & N/A \\
\hline UNICEF & 7,227 & 6,997 & 9,065 & 6,560 & 3,375 & N/A \\
\hline $\mathrm{ADB}$ & 509 & 5,500 & 4,600 & 5,200 & 3,200 & N/A \\
\hline Sweden & 11,948 & 7,914 & 3,975 & 139 & N/A & N/A \\
\hline World Bank & 7,489 & 1,736 & 3,888 & 9,171 & 10,801 & N/A \\
\hline Japan & 6,503 & 8,987 & 3,714 & 2,834 & 2,719 & N/A \\
\hline Republic of Korea & 1,432 & 3,723 & 2,649 & 2,800 & N/A & N/A \\
\hline New Zealand & 3,082 & 1,128 & 2,635 & 550 & 852 & N/A \\
\hline USA & 6,334 & 7,206 & 2,233 & N/A & N/A & N/A \\
\hline Total amount from the 10 donors & 55,503 & 60,599 & 71,820 & 55,871 & 21,310 & N/A \\
\hline Total amount from the all donors & 55,837 & 61,358 & 90,484 & 58,258 & 21,624 & N/A \\
\hline
\end{tabular}

Source: Education congress: The education, youth, and sport performance in the academic year 2015-2016 and goals for the academic year 2016-2017.

World Bank in Cambodia HE. IDA plays as an important role on HE in Cambodia financing from the World Bank designing a prestigious project called Higher Education Improvement Project (HEIP, P162971). This project was prioritized and designed to solve the finding challenges related to the review of education equity in Cambodia including poverty vs. access to education, remoteness vs. access to education, and gender vs. access to education. Additionally, the assessment findings were also higher demand for accommodation, concern over living in the big city, lack of financial support, lack of foreign language skill, lack of computer 
and information technology (IT) related skill, lack of support for disable student, lack of modern and up-to-date laboratory and library, and lack of electricity. In order to solve these barriers and improve equity in HE, the key solutions pointed out the two measures specifically and generally. For specific measures focused on provision of scholarship and/or emergency fund, construction and/or renovation of dormitory, provision of English language class, provision of computer literacy class, establish mentorship program, and organize academic year orientation day and city tour. Moreover, for general measures, they were about provision of modern laboratory, equipment, and consumable; provision of modern library; provision of computer laboratory; and provision of backup generator. The proposed project of IDA was targeting in two priority areas: Firstly, it mains to improve the quality, relevance, and equity of education and research at some selected HEIs. And secondly, the project improves the governance sector and provides immediate and effective response in case of an eligible crisis or emergency. The project was responded by two components and five sub-components. The prestigious project and its components will discuss in detail as follows:

Component 1: Improving STEM and Agriculture education and research at selected HEIs. It divides into three sub-components:

Sub-component 1.1: Improving teaching and learning. Main activities include: (a) upgrading of curriculum and teacher qualification in target programs; (b) establishing new graduate programs; and (c) constructing and rehabilitating university buildings, classrooms, and students' dormitories;

Sub-component 1.2: Improving research. Main activities include: (a) constructing and rehabilitating laboratories; (b) providing research equipment and consumables; and (c) providing research funds;

Sub-component 1.3: Improving institutional management. Main activities include: Supporting financial management (FM) and human resource management (HRM) reform, and tracer studies or student performance assessment.

Component 2: Strengthen Sectoral Governance and Project Management. It classifies into two different sub-components:

Sub-component 2.1: Strengthening Sectoral Governance. Main activities include: (a) supporting legislation for sectoral reform; (b) improving quality assurance mechanism; and (c) expanding information system;

Sub-component 2.2: Strengthening Project Management. Main Activities include supporting project coordination and management (World Bank, 2017a).

UNESCO in Cambodia. UNESCO has worked as one of the key advisors who helped to guide HE policies, printed and disseminated to the other key stakeholders both public and private HEIs. With this help, Cambodia can stand for competition in term of policy, mobility, and quality assurance in HE regionally and globally (UNESCO, 2010). Strategically, UNESCO planned to promote policy dialogue, research, and analysis on challenges caused by new development and reforms. This plan would improve the quality assurance and recognition of qualifications, university governance and management, and effective use of ICT in broaden access and enhancing the quality of education. Research findings are the main evidence-based information to proof with policymakers and education practitioners. So, UNESCO would role to help Cambodia in preparing, creating, and enabling the culture of conducting research. Within this research promotion, UNESCO would give four domains procedures by providing advisory services for the formulation of research policy; providing technical assistance to conduct research and analysis of education issues of common concern to Cambodia; providing advisory services for capacity development of researchers, disseminating research results, and providing support for research; and immersing Cambodia to international and regional development in the field 
of educational research (UNESCO, 2010).

Recently, in the field of HE in Cambodia, UNESCO has supported MoEYS to initiate the policy of HE vision 2030 under the vision of "building a quality HE system that develops human resource with excellent knowledge, skills, and moral value in order to work and live within the era of globalization and knowledge-based society”. Moreover, this policy' goal is to develop a good governance and HE mechanisms to make sure that the adequate students can enjoy HE in order to promote economic development and become active citizenship (MoEYS, 2014). Obviously, the policy was designed with four interrelated objectives:

1. Create a comprehensive equity and access program that ensures all qualified students have the opportunity to study at HEIs and complete a quality program;

2. Develop relevant curricula that provide students with excellent knowledge and skills that help them contribute fully to national development and labour market needs;

3. Improve quality of learning, teaching, and research systems to provide students with knowledge and skills needed in the labour market and contribute to the national development;

4. Develop a governance system, mechanisms and policies for HE, which enhance the quality of management and performance of HEIs and other relevant institution (MoEYS, 2014).

On the other hand, the policy has set eight clear strategies accompanied by many potential sub-strategies and the unclouded procedure of action plan. The establishment of this effective design policy in HE is to prepare Cambodia for the 2030 Agenda for Sustainable Development Growth (SDG) especially to produce qualified Cambodian graduates for labor market needs to ensure inclusive and equitable quality education and promote lifelong learning opportunities for all.

France in Cambodia HE. Different from other donors bilaterally, multilaterally, and privately who help general or basic education. France fully operates the project on HE of education sector in Cambodia. France's cooperation programs are to strengthen HE system which "is a crucial for reconstruction of intellectual elite in every field” (UNESS, 2010). The mains aims of France's support are to help re-structure HE in the country's universities; to set up existing curricula in an undergraduate-mater-Ph.D. degree context; and to develop new curricula in order to form able professionals in sectors that are in demand. The project would be exceeded 2.7 million USD for implementation on the fields of human sciences, engineering, agronomy, law, economics, management, and health.

Australia's Aid Program in Cambodia HE. Australia has a lot of projects to help Cambodian government include: Australia-Cambodia Development Cooperation Strategy 2003-2007, Australia-Cambodia Development Cooperation Strategy 2008-2015, Australia-Cambodia Joint Aid Program Strategy 2010-2015, and Australian-Cambodia Development Scholarship (ADS). These agencies support different fields to help Cambodia. In term of HE, only ADS provides scholarship for Cambodian students. The program aims to help public sector in the Royal Government of Cambodia by improving management and technical capacities which contributed 17,201,573 USD from 1995 to 2009. Under this program, AID provides scholarship to Cambodia students at post-graduate levels, supports government staff and a few general applicants.

Japanese International Cooperation Agency (JICA) in Cambodia HE. Similarly, in the field of education, JICA invested 6,112,185 USD for running five projects to help Cambodian government. Those projects include Library Activity Enhancement and Physical Education, the Cambodia-Japan Cooperation Center, Japanese Overseas Cooperation Volunteers and Senior Volunteers, Science Teacher Education, and Volunteer Program for Regional Teacher Training Centers. In term of HE improvement project, the same as 
AusAID, Japanese Japan has provided scholarships for Cambodia government staff every year to obtain both Master and PhD levels.

\section{Financing HE in Nigeria}

The major goal of Nigerian tertiary education is the production of community of Nigerians that are highly skilled and well prepared for the world of labor market, sustainable national development, and global competitiveness in terms of expertise. However, the government has shown deep concern over the years about the adequacy of the institution of higher learning in preparing graduates for the world of work and for global competitiveness. In Nigeria, the demand for popular education is so high, because education is not only an investment in human capital, but also a pre-requisite as well as a correlate for economic development (Adeyemo, 2000). The belief that education is an engine of growth rests on the quantity and quality of education in any country. The Federal Government of Nigerian (2004) explicitly stated that education is a government affair in which free education is to be provided by the government at all levels when and practicable. The public sector is the major provider and financier of education in Nigeria since it took over most of the schools in the country from primary to tertiary level in the mid-1970s. Since 1999, National Economics Empowerment Development Strategy (NEEDS), education has remained one of the most challenging agenda enunciated by most late and present administrations on assumption of office. The 1999 Vision and 2000-2020 Document underline the importance of education as a vehicle of both individual empowerment and national development. In spite of the strategies and reforms, there was really nothing on ground to inspire confidence in the national economy. The universities and other tertiary institutions were in a state of advanced decay with most of the teaching staff leaving the country in droves in search of greener pastures abroad. Apart from the impact of inadequate funding on the quality of the teaching and learning process in the institute of HE, students support is now inadequate. The number of students from poor and disadvantaged background attending the higher institutions has become insignificant. The funding of HE has been regressive over the years. It was therefore not surprising that the late Yar' Adua's administration had to be confronted by labour unions in the education sector with long lists of demands on what should be done to uplift the sector. The unions, one after the other had to embark on debilitating strike actions to press home their points. The ensuing face-off-between the Federal Government and Academic Staff Union of Universities (ASUU) resulted into the shutting of the universities for close to four months. Furthermore, Imhabekhai and Tonwe (2001) also highlighted that currently, universities education at present is underfunded, inadequate funding put the university management under stress and strains, hence, they are incapacitated in providing essential services. This has led to rampant crises in the system resulting in strikes by academic and non-academic staff, dearth of equipment and facilities, indiscipline among staff and students, upsurge in the activities of secret cults among others. HE relates to all forms of post-secondary education, such as the universities, polytechnics, colleges of education, monotechnics, and professional schools (Abdu, 2003). In the quest for development, developing countries have acknowledged that investment in (and) adequate funding of $\mathrm{HE}$ are viable, conditions that facilitate change since the value of education hinges on teaching, learning, research, and the production of qualified personnel which are needed for national development (UNESCO, 2002).

Oghenekohwo (2004) classified the funding of HE into two regimes, which are prederegulation regime and deregulation regime. In the pre-deregulation regime, HE funding in Nigeria was done by government or public funding alone. High priority was accorded to funding HE, thereby creating a wrong impression amongst 
Nigerians that funding of HE is the exclusive preserve of "governments". On the other hand, in the deregulation regime, this is mostly a post Structural Adjustment Programme (SAP) inevitability, things began to change. The benefits of the acquisition of any HE programme now went largely to the individual as a "private good" for which beneficiaries and their families should pay (Schuttz, 1961; Psacharopoulos, 1984; Babalola, 1995; Adedeji \& Babalola, 2003; Okebukola, 2003). Okebukola (2003) noted that "An additional concomitant of the 'private good' is that, grants have been changed to loans, pacing major burdens on many university graduates”. Educational outcomes are products of the complex interactions of the different stakeholders who participate directly in the schooling process (parents, teachers, students, administrators, ministries, etc) and other agents not directly connected to the educational system. The financing of education should be the function of all the major stakeholders. This is because government alone cannot fund HE. According to Udoh (2008), because Nigeria is a developing nation, it is currently witnessing increase in enrolment of university students. This increase in enrolment demands corresponding increase in funding which is not the case in Nigeria. Fund allocation does not increase to meet the demand of funds occasioned by the enrolment increase. Abdu (2003) confirmed that the unfortunate expectation of both parents and students are apprehensive of any new initiative in the management of tertiary institution to mean introduction of tuition fees. There still exist difficulties on the higher institutions especially on the universities to meet her only $10 \%$ internal fund generation quote despite the normal government subventions (allocation) to universities. These can only be facilitates through adequate financing.

National Board for Technical Education (NBTE) and National Commission for Colleges of Education (NCCE) in Nigeria. The mandates and the functions of the NBTE and the NCCE for the management of the polytechnics and colleges of education systems are similar to those indicated above for the NUC. Particularly note worthy is the establishment of credible systems of programme accreditation by the NBTE and the NCCE towards quality assurance. These agencies are also responsible for the processing of applications for the establishments of private polytechnics and colleges of education respectively in the country.

Effects of Inadequate Funding on Tertiary Institutions in Nigeria. Nigeria has witnessed a significant growth in terms of expansion of access through increase in enrolment and establishment of additional institutions. However, it is obvious and alarming that many of the indices that can guarantee qualitative HE are not taken into consideration in the country's quest to meet quantitative target. It has been observed that political factors are the main motives behind many of the expansion polices especially in the university system (Ekundayo, 2008). In fact, capital projects to meet the expanding programmes could not take off, in case where they took off, they had to be abandoned due to lack of funds. The result, according to Ekundayo (2008), was a summon table pressure on the available limited resources, thereby, resulting in downward pressure on staff salaries together with deteriorating working conditions. The effect includes high degree of "brain-drain” among the academic staff, incessant strikes action, students' riots, and lecture boy-cots, etc. All these will have a by-effects in the quality of HE in Nigeria. Akintoye (2008), in his own view, posited that the by-effects of dwindling fiancés in higher institutions (Nigeria University) are explicated in many mechanisms, such as:

1. Curtailment of laboratory/practical classes;

2. Limited number of field trips;

3. Curtailment in the attendance of academic conferences;

4. Curtailment of the purchase of library books; 
5. Chemicals and basic laboratory equipment freezing of new appointments;

6. Virtual embargo on study fellowships and reduction in research grants;

7. Too narrow strategic profiles and core areas;

8. Loss of variety in research and teaching;

9. Dangerous close down of studies not in demand at present or expensive (unprofitable) studies;

10. Loss of autonomy through increased dependence from external principals (third party funding);

11. Internal centralization and expansion of administration;

12. Increased administrative burdens at the expenses or research and teaching;

13. Reduced coordination (harmonization) between universities because of increased competition.

Possible Sources of Funding HE in Nigeria. The major challenge of HE in Nigeria today is the problem of finance. The political, social, and economic factors, which are currently having significant impact on the world economy, have necessitated the need to diversify the sources of education funding, mainly because reliance on only one source of revenue can inhibit educational growth (Akinsanya, 2007). He, therefore, highlighted these as some possible options of financing HE as follows:

1. Fund from owner government;

2. Private contributions by commercial organizations in the form of occasional grants for specific purposes;

3. Tuition and fees;

4. Gifts, grants, and endowments;

5. Investment income;

6. Auxiliaries (Enterprises, Licenses, Parents, and Alumni Association);

7. Consultancies and research activities;

8. Community participation, etc.

Ogunlade (1989) also added others which include support from federal and state governments constituting more than $98 \%$ of the recurrent costs and $100 \%$ of capital cost and about less than $2 \%$ from international aids from IOs (as indicated in Table 5). Around 1998, the World Bank has financed a US\$ 120 million project titled Federal Universities Development Sector Operation (Odebyiyi \& Aina 1999, Babalola, Sikwibele, \& Suleiman, 2000).

Factors Affecting Cost and Financing of $\mathrm{HE}$ in Nigeria. The following factors are some basic factors affecting finance of HE in Nigeria (Fagbulu, 2003):

1. Data and population;

2. Student-teacher ratio (STR), average teacher salaries (ATS), and students enrolment rate (SRT);

3. Goals and objective of education;

4. Development needs of the nation;

5. Human innate needs to learn;

6. Political exigencies;

7. Resource management level;

8. Staff (manpower) capacity;

9. Economic crises in the country.

Apart from these, Akintayo (2004) highlighted some problems in financing of university education in Nigeria as the following: 
1. Pegging of admission by governments;

2. Very low educational budget by the government;

3. Dwindling financial support from foreign donors/international organization;

4. The economic growth in Africa is no longer strong enough to fund programmes in HE;

5. Poverty, unemployment, and uneven distribution of wealth;

6. High tuition charges by private HE providers, e.g., Igbenedion University collects about (N1.3 million), Babcock (N1.2 million), Bowen (N9 million), etc. All these are not possible for indigent students who have prospect for HE;

7. Limited numbers of HE providers, both private and community organizations have not invested enough on HE;

8. In the light of these, all stakeholders must be involved in the provision of university education through integrated approach to university education finance.

IOs and Education Projects in Nigeria. It is very difficult to find trending literature on impacts of the IOs on HE on any national economy. This is partly due to the fact that there is almost no empirical work on the subject matter; and secondly, there seems to be no individual country's analysis of impact of the efforts of IOs. Also, almost all the IOs have not had impact on the country's HE. The little available information on this concerns project locations and value estimates (cost estimates) presented on the World Bank's institution's website. Only the World Bank seems to have documented impacts on HE in Nigeria, hence the few citations focus on the impact of the World Bank.

The World Bank Group (WBG) appears to be the largest external financier of education in developing countries, from pre-primary and primary education through HE. Since 2000, the WBG has invested more than US\$45 billion in education (World Bank, 2018). However, evidences abound that bulk of this spending is domiciled in pre-primary, primary, and secondary education levels.

More importantly, nations that mainly benefited from most of this financial resources committed by the WBG include Cambodia, Senegal, Democratic Republic of Congo, Mongolia, Haiti, Niger, Mauritania, Tajikistan, The Gambia, Ethiopia, and Sudan (World Bank, 2018).

In 2017, the World Bank planned to invest $\$ 70 \mathrm{~m}$ on Nigerian varsities. This was intended to affect 10 universities in Nigeria which are Redeemers University, Ahmadu Bello University, University of Jos, University of Benin, Africa University of Science and Technology, University of Port Harcourt, Obafemi Awolowo University, Bayero University, Benue State University, and Federal University of Technology (Vanguard Newspaper, 2017).

Presentation of Findings. Of all the IOs considered in this study, only the World Bank has well documented impact projects in Nigeria. The World Bank impacts on HE in Nigeria in three main areas, which are research, scholarship, and finance. These facts which represent the main focus of this work are substantiated below.

From Table 5 presented below, it can be observed that projects embarked upon by the World Bank in Nigeria between 1958 and 2018 are 235 in all. Of this, 16 were targeted at education sector while HE (subset of education sector) got two of them (less than $1 \%$ of the entire projects).

Also, the World Bank extends its HE support to Nigeria via research. This is made possible by including Nigeria in the list of countries whose macro-economic time-series data are published on World Development Indicators. This has helped researchers at HE level to conduct good and reliable researches. 
Table 5

Computed by the Author From World Bank Data

\begin{tabular}{|c|c|c|c|c|}
\hline \multicolumn{5}{|c|}{ World Bank Intervention Projects in Nigeria and Estimates of Worth (1958-2018) } \\
\hline $\begin{array}{l}\text { Sectors of World Bank } \\
\text { Intervention }\end{array}$ & Number of Projects & Percentage (\%) & Amount Committed & Percentage $(\%)$ \\
\hline Education Sector & 16 & 6.8 & $1,776.3$ & 6.7 \\
\hline $\mathrm{HE}$ & 2 & 0.85 & 222.4 & 0.84 \\
\hline $\begin{array}{l}\text { Other levels (pre-primary } \\
\text { primary, and secondary } \\
\text { education) }\end{array}$ & 14 & 5.95 & $1,553.9$ & 5.86 \\
\hline Other Sectors & 219 & 93.2 & $24,777.24$ & 93.3 \\
\hline Total & 235 & 100 & $26,553.54$ & 100 \\
\hline
\end{tabular}

The World Bank has also supported HE in Nigeria by sponsoring supporting qualified candidates to pursue degrees in a number of universities in developed countries. This is made possible through annual World Bank Scholarship Programme for both undergraduate and postgraduate studies. It also offers Fellowship Training Programme (post-doctoral research). Nigeria happens to be one of the beneficiary countries among others.

Other IOs and HE in Nigeria. While it has been established that other international agencies involved in the study affect Nigeria as a nation, most of them do not necessarily impact on HE in Nigeria. Obviously and as contained in Table 5, the World Bank has somewhat impacted on Nigeria's education sector, having undertaken a total of 16 projects (with only two on HE) in 60 years.

Unfortunately, many of other IOs assist Nigeria's education sector at other levels of education, such as pre-primary education, primary education, and secondary education. For example, activities of the UNICEF and UNESCO have focused on childhood education and educational policy prescriptions, respectively. UNICEF's impact, by concentrating in the area of childhood education and health, helps to strengthen foundation for further levels of education. These roles are commendable, because quality of HE relies, to a large extent, on the quality of previous educational levels.

UNESCO, via its educational policy recommendations, also helps Nigeria operate in line with best global educational practices. This UNESCO's role though qualitative and subjective, is something to write home about. UNESCO, by recommending that more be budgeted to education sector and guiding on policy frameworks to boost educational access for all, helps to guide policymakers in Nigeria's education sector to advocate for adequate financing.

The NGOs operating in Nigeria have been supporting education sector in one way or the other. For example, some of them (especially the locally-based) have supported HE through award of scholarships to indigent and hardworking students.

IMF concentrates on helping economies maintain stable exchange rate and improve balance of payment positions.

There is no established documented project that has ever been recorded undertaken by IMF on HE in Nigeria. The same explanation holds for other IOs. The only exception is the World Bank with evidence of impact projects well documented. This does not imply that IMF has not been supportive to Nigeria in other sectors and contexts. 


\section{Conclusions and Recommendations}

\section{Conclusions}

The World Bank concentrates on and pays more attention to pre-primary, primary, and secondary education and largely lessons on HE in Nigeria. This may be partly due to its target of raising literacy level and enrollment rates up to the college level. With about 60 projects undertaken in Nigeria between 1958 and 2018, only 16 affected education sector. Out of these 16 projected, only two affected HE.

The World Bank documents only projects and associated costs it commits itself into for each country. Surprisingly, the World Bank seems to be the only IO executing developmental projects on HE in Nigeria. This study also finds that empirical study on impact of the World Bank and other IOs on HE is almost non-existent.

World Bank's role on HE in Nigeria, though most dominant, obvious and in the class of IOs, is very minimal and insignificant in relative context. This is evident from the proportion of its projects committed to education in Nigeria out of all projects conducted so far for the entire period of 60 years (1958-2018).

\section{Recommendations}

Given the fact that HE in Nigeria is plagued by low quality arising from poor learning facilities and environment, it is recommended that the World Bank should help developing countries including Nigeria to raise facilities and general learning conditions in HE.

More attention should be given to HE since other level of education such the basic education and secondary level has so far benefitted more from World Bank.

This calls for consolidating existing projects with more projects that will help improve existing status and face of HE in Nigeria.

It is also recommended that all other IOs, such as IMF, UNICEF, UNESCO, EU, UN, NGOs, and others should focus to impact more on Nigeria and Cambodia HE if truly quality education is desired for both countries. In other words, desiring quality education for Nigeria and Cambodia should not only be in terms of making recommendations, but also in terms of helping to boost facilities.

The Nigeria and Cambodia government should shift more attention to the urgent needs of HE rather than lower education. The need for IO/foreign aids to invest more for the development of HE in both countries should be highly emphasize by their government/ministry of education.

The IO should draw out a clear requirement plan/policy/criteria without any biase in supporting each country HE. Each country should enhance in accordance to their peculiar challenges.

And lastly, on Nigeria HE, the World Bank should also give more priority and attention to education in general by raising more found rather than other sectors of the economy.

In Cambodia, more international organization should join in hands to work together with the World Bank, UNESCO, IMF, etc. in order to complete the mission of providing equity and quality of education.

To maintain the standard purpose of HE in Cambodia, all international organization should strive to monitor the trends and programs of education reform and development in Cambodia. IOs should additionally support and enhance quality of HE, prepare equity of accessing for HE, provide ideas of conducting researches and provide plenty scholarship opportunities for Cambodian Government staff to pursue HE in international context. 


\section{References}

Abdu, P. S. (2003, June). The cost and finance of education in Nigeria. Education Today Quarterly Magazine, 10(1), 12-16.

Adedeji, S., \& Babalola, J. (Eds.) (2003). Contemporary issues in educational management: A book of Honour. Ibadan: Department of Educational Management.

Adeyemo, B. (2000). Public school funding: The case of community mobilization and effective and effective management. Journal of Educational Development, 1.

Akintayo, M. O. (2004, January-June). Public financing and the problems of access to university education. International Journal of Literacy Education, 2, 1-23.

Akintoye, I. R. (2008). Optimizing output from tertiary educational institutions via adequate funding: A lesson from Nigeria International Research Journal of Finance and Economics, 14, 192.

Akinsanya, O. O. (2007). Financing higher education in Nigeria, College of Applied Education and Vocational Technology, Tal Solarin University of Education, Ijebu-Ode, Ogun State. International Journal of African \& African American Studies, 6(1).

Benveniste, L., Marshall, J., \& Araujo, M. (2008). Teaching in Cambodia. The World Bank and Ministry of Education, Youth, and Sport, 44850, 1-120.

Babalola. J. B. (1995). Education costs and financing analysis ESP distance learning centre. Nigeria: University of Ibadan.

Babalola, J. B., Sikwibele, A. L., \& Suleiman, A. A. (2000). Education as aided by the World Bank: A critical analysis of post independence projects in Nigeria. Journal of Third World Studies, 17(1), 155-163.

Bloom, B. S. (Ed.). (1956). Taxonomy of educational objectives, Handbook I: Cognitive domain. New York: McKay.

Cambodia’s Leading Independent Development Policy Research Institute (CDRI). (2012). Understanding poverty dynamics: Evidence from nice villages in Cambodia. In Working Paper Series No. 69. Phnom Penh: CDRI.

Cheat, C. (2005). Cambodia. In Higher education in South East Asia (pp. 13-33). Bangkok: UNESCO Asian and Pacific Regional Bureau of Education.

Chet, C. (2009). Higher education in Cambodia. In Y. Hirosato and Y. Kitamura (Eds.), The political economy of education reforms and capacity development in southeast Asia-Cases of Cambodia, Laos and Vietnam: Education in the Asian-pacific region series: Issues, concerns and prospects (Vol. 13). Springer Science + Business Media B.V.

Chhinh, S. (2004). Factor related to mathematics achievement of urban primary school students in Cambodia. Tokyo: The Fuji Xerox Document Company.

Chhinh, S. (2016). The way forward for education reform in Cambodia: Issues of quality and equity. In Y. Kimtamura, D. B. Edwards, S. Chhinh, and J. H. Williams (Eds.), The political economy of schooling in Cambodia: International and development education. New York: Palgrave Macmillan.

Chhinh, S., \& Dy, S. S. (2009). Education reform context and process in Cambodia. In Y. Hirosato and Y. Kitamura (Eds.), The political economy of education reforms and capacity development in southeast Asia-Cases of Cambodia, Laos and Vietnam: Education in the Asian-pacific region series: Issues, concerns and prospects (Vol. 13). Springer Science + Business Media B.V.

Chhihn, S., Ewards, D. B., James, Williams, J. H., \& Kitamura, Y. (2016). Introduction. In Y. Kimtamura, D. B. Edwards, S. Chhinh, and J. H. Williams (Eds.), The political economy of schooling in Cambodia: International and development education. New York: Palgrave Macmillan.

Dy, K. (2007). A history of democratic Kampuchea (1975-1979) (pp. 1-4). Phnom Penh, Cambodia: Documentation Center of Cambodia.

Dy, K. (2013). Challenges of teaching genocide in Cambodia secondary schools. Documentation Center of Cambodia. Policy and Practice: Pedagogy about the Holocaust and Genocide Papers, Paper 4, 1-10.

Dy, S. S. (2004). Strategies and policies for basic education in Cambodia: Historical perspectives. International Education Journal. 5(1), 90-97.

Dy, S. S. (2013). Case study: The effectiveness of research and innovation management at policy and institutional levels in Cambodia. In A. Olsson and L. Meek (Eds.), Effectiveness of research and innovation management at policy and institutional levels: Cambodia, Malaysia, Thailand and Vietnam (pp. 75-89). OECD: Program on Innovation, Higher Education and Research for Development (IHERD).

Ekundayo, T. A. (2008). Expanding access to higher education in Nigeria: The question of quality control. Journal of Reforming Higher Education in Africa, 22, 36.

Fagbulu, O. (2003). Cost and finance of education. Education Today Quarterly, 10(1), 2-5. 
Federal Government of Nigeria. (2004). National policy on education. Lagos: FGB Printer.

Hattori, H. (2009). Enhancing aid effectiveness in education through a sector approach in Cambodia. Prospects, 9(2), 185-199. DOI 10.1007/s11125-009-9121-2. UNESCO IBE 2009: Springer.

Imhabekhai, C. I., \& Tonew, D. A. (2001). Funding higher education in Nigeria. Ibadan: Powerhouse Publishers.

Keng, C. S., \& Clayton, T. (2007). Schooling in Cambodia. In G. A. Postiglione and J. Tan (Eds.), Going to school in Asian. Westport, CT: Greenwood Press.

Kim, C. Y., \& Ruose, M. (2011). Reviewing the role of teachers in achieving education for all in Cambodia. Prospects, 41(3), 415-428. DOI 10.1007/s11125-011-9201-y. UNECSO IBE 2011: Springer.

Ministry of Education, Youth, and Sport (MoEYS). (2005). Education sector support program. Phnom Penh: MoEYS.

MoEYS. (2014). Policy on higher education vision 2030. Phnom Penh: MoEYS.

MoEYS. (2015). Teacher policy action plan: Teacher training department. Phnom Penh: MoEYS.

MoEYS. (2016). Action plan for human resource in education sector. Phnom Penh: MoEYS.

MoEYS. (2017). Education congress: The education, youth and sport performance in the academic year 2015-2016 and goals for the academic year 2016-2017. Phnom Penh: MoEYS.

MoEYS, \& World Bank. (2015). Stocktaking report-Higher education quality and capacity improvement project: Development and Innovation Grants. Phnom Penh: MoEYS and World Bank.

Odebiyi, A. I., \& Aina, O. I. (1999). Alternative modes of financing higher education in Nigeria and implications for university governance. Final Report, Accra: Association of African Universities (AAU).

Oghenekohwo, J. E. (2004, January-June). Deregulation policy and its implication of the funding of the university education in Nigeria. Journal of Research on Education, 3(1), 204-224.

Ogunlade, A. L. (1989). Locating supplemental sources of revenue to finance universities in Nigeria. Journal of Education Finance, 14(4), 522-533.

Okebukola, P. (2003). Issues in funding university education in Nigeria. Abuja, MUC: NUC Monograph Series.

Pith, C., \& Ford, D. (2004). Cambodian higher education: Mixed visions. In P. G. Altbach and T. Umakoshi (Eds.), Asian universities: Historical perspectives and contemporary challenges. Baltimore, MD: The Johns Hopkins University.

Psacharopoulos, G. (1984). The Contribution of education to economic growth international comparisons. In J. Kendrick (Ed.), International productive comparisons and cause of the showdown. Ballenger: Cambridge Mass.

Schuitz T. W. (1961). Education and economic growth. In M. B. Henry (Ed.), Social forces influencing American education. Chicago: National Society for the Study of Education, University of Chinago Press.

Sen, V., \& Ros, S. (2013). Anatomy of higher education governance in Cambodia. In Working Paper Series No. 86. Phnom Penh: CDRI.

Shaeffer, S., \& Heng, K. (2016). Joint formative evaluation of child-friendly school policy implementation in Cambodia. In Final Report: United Nations Children's Fund (UNICEF). Phnom Penh: UNICEF.

Udoh, G. (2008). Alternative sources of funding university education in Nigeria. International Multi-Disciplinary Journal, 2(3), 98-110.

UNESCO. (1998). Higher education in the twenty-first century vision and action. Paris: UNESCO.

UNESCO (2002). Higher education in the twenty first century vision and actions. Paris, UNESCO.

UNESCO. (2008). Asian and the Pacific education for all (EFA) mid-decade assessment: Mekong sub-region synthesis report. Bangkok: UNESCO.

UNESCO National Education Support Strategy (UNESS). (2010). Cambodia 2010-2013: UNESCO National Education Support Strategy. Phnom Penh: UNESCO.

Vanguard of Nigeria. (2017). Retrieved from https://ww.vanguardngr.com/2017.05/word-bank-invets-70m-nigerian-versities-2

Williams, J. H., Kitamura, Y., \& Keng, C. S. (2016). Higher education in Cambodia: Expansion and quality improvement. In Y. Kimtamura, D. B. Edwards, S. Chhinh, and J. H. Williams (Eds.), The political economy of schooling in Cambodia: International and development education. New York: Palgrave Macmillan.

World Bank. (2002). Constructing knowledge societies: New challenges for tertiary education. Washington: World Bank.

World Bank. (2017a). Higher education improvement project (HEIP)-Cambodia: Equity assessment and equity plan. Project Number: P162971. Phnom Penh: World Bank.

World Bank. (2017b). Higher education improvement project (HEIP): Environment and social management framework. Project Number: P162971. Phnom Penh: World Bank.

World Bank. (2018). The global partnership for education and the Word Bank: The facts. Retrieved from http://www.worldbank.org/en/topic/education/brief/the-global-partnership-for-education-and-the-world-bank-group-the-facts 